\title{
1 Fractures in mudrocks: advances in constraining timing and understanding mechanisms
}

2 J.N. Hooker ${ }^{1,2}$

3 I. S. Abu-Mahfouz ${ }^{1}$

4 Q. Meng ${ }^{1}$

5 J. Cartwright ${ }^{1}$

6

7 1. University of Oxford, Department of Earth Sciences, South Parks Road, Oxford OX1 3AN, United

$8 \quad$ Kingdom

9

10 2. Pennsylvania State University, Department of Geosciences, 503 Deike Bldg., University Park,

11 Pennsylvania, 16802

12

13 ABSTRACT

14

15 Recent advances in fracture-timing techniques have led to new insights about sequences and mechanisms

16 of fracture formation in mudrocks. Methods to constrain fracture timing in mudrocks include: (i) field

17 evidence, including crosscutting relationships and evidence of compaction; (ii) petrographic evidence,

18 including signs of soft-sediment deformation and diagnostic mineral assemblages or textures; (iii) stable-

19 isotopic evidence; (iv) thermometric dating using burial history modelling; and (v) radiometric age-

20 dating. In this contribution, we briefly review each method with salient examples from the literature.

21 Many documented examples of mudrock-hosted fractures formed during early burial, a non-intuitive

22 finding that demands a re-assessment of our assumptions about what types of materials can develop

23 opening-mode fractures. In general, the style and distribution of fractures varies dramatically based on

24 fracture timing, highlighting the importance of constraining timing for predicting fracture patterns and

25 interpreting their mechanisms, including the role of fluid flow. 
KEY WORDS

31 Fracture; Fracture timing; Mudrock; Shale; Geomechanics

\section{INTRODUCTION}

35 Fractures preserved in mudrocks have several characteristics that hint that a special set of fracture mechanisms might apply to mudrocks as opposed to sandstones, carbonates, and other rock types.

37 Mudrock fractures are more commonly layer-parallel and filled by fibrous crystals, which may or may not include host sediment. These observations, along with mudrocks' low porosity, high organic content, and high content of relatively soluble minerals, have led previous researchers to attribute mudrock-hosted fracturing as much to diagenesis (Hooker et al., 2017a) or catagenesis (Jochum et al., 1995) as to

41 tectonically induced stresses.

42

43 Whatever their cause, fractures in mudrocks are important for evaluating cross-stratal fluid migration 44 mechanisms, deformation styles, and sealing capacity. Indeed, little consensus exists about the extent to 45 which fluids move within the crust (Deming et al., 2002; Osborn et al., 2012; Bjørlykke, 2014), and the 46 natural fracturing of low-permeability rocks is a key process by which subsurface fluid flow could be 47 enabled. However, fracture timing is difficult to constrain, and without knowing when fractures formed, 48 ascribing fractures to a given specific mechanism, whether involving fluid flow or not, is problematic. In 49 this paper, we briefly review the available techniques for constraining the timing of fractures in 50 mudrocks. We synthesize results of fracture timing studies to date in order to draw general conclusions 51 about how and when fractures develop in mudrocks, and to suggest potential useful avenues for future 52 research. 
54 The scope of this work is the timing of fractures in mudrocks, which we identify as structures having 55 opening displacement and some fill consisting of minerals or organic matter. This first criterion omits

56 faults from our consideration, although shared crosscutting relationships and mineral assemblages, as well

57 as parallel strikes, commonly indicate cogenetic mechanisms for faults and opening-mode fractures.

58 Mineral and organic fills aid the interpretation of fractures because they demonstrate the fractures'

59 prolonged exposure to natural subsurface fluids; moreover these fills provide evidence for the fluid

60 chemistry and timing of fracture formation. In many cases, barren or mostly-barren fractures are believed

61 to have escaped cementation, perhaps because of gas driving off water (Engelder and Whitaker, 2006),

62 and so the suppression of cementation is a topic of major current interest, but is outside the scope of the

63 present work.

64

65 Furthermore, laboratory experiments on mudrocks support the importance of rock properties for

66 determining fracture intensity and distribution (Ingram and Urai, 1999), of pre-existing fractures and

67 fracture fills on fracture orientation and localization (Gale and Holder, 2010), and of migrating fluids on

68 fracture initiation and coalescence (Cobbold and Rodrigues, 2007). Laboratory experiments are

69 particularly illuminating for predicting the behaviour of artificial hydraulic fractures, which take place on

70 similar, short time scales. But, owing to the geological pace of natural fracture growth, comparisons of

71 natural and artificial fractures need to be made with care, and are not treated here.

72

73 Given the complexity of the topic and the format of this special issue, we restrict our attention to

74 mesoscale structures that would be observed in field exposures or core samples. Published examples of 75 opening-mode fractures in mudrocks reach widths of up to several $\mathrm{cm}$ (Gale et al., 2014) and lengths of 76 up to a few hundred $\mathrm{m}$ (Lash et al., 2004). Rarely are opening-mode fractures unambiguously mappable at 77 scales of 1:100 or greater. 
82

83 The most fundamental timing constraint for geologic fractures is that they are younger than the rock that

84 they cut. Beyond this constraint, fractures can be altered by geologic processes, which can thereby be

85 interpreted to post-date the fractures. An important example is ptygmatic folding of steeply dipping

86 cement-filled fractures in sedimentary rocks. Such ptygmatic folds have been interpreted to form by

87 compaction of the fracture, implying that the sediment fractured well before the consolidation process was complete (Hiscott, 1979; Karner and Shillington, 2005; Gale, 2014; Hooker et al., 2017a).

Fractures can also be overprinted by cleavage or other secondary rock textures (e.g. Torremans et al.,

91 2014). Engelder et al. (2001) pointed out that uncemented fractures in the Appalachian Plateau appear to

92 keep a pristine appearance despite considerable pressure solution postdating the fractures. They suggested 93 that methane might inhibit alteration of fracture faces.

94

2.2. Petrographic evidence

96

97 Textures that are ambiguous in hand-sample may be more easily interpreted by microscopic examination.

98 In particular, diffuse deformation could result from crystal plasticity, closely spaced stylolites, or grain-

99 boundary sliding in unconsolidated sediment. These processes imply high, moderate, and low burial

100 temperature-pressure regimes, respectively. Grain-boundary sliding would be expected to be the most

101 important deformation mechanism during the earliest stages of lithification. However, note in Figure (1)

102 the microfracturing within inner arcs of ptygmatically folded veins. The vertical strain recorded by

103 flattening of these veins is on the order of -0.5 , indicating that fracturing is a potential deformation

104 mechanism very early in the mudrock burial sequence. 
106 Moreover, shale laminae "wrap around" calcite veins (Figure 2) that were interpreted to result from deep

107 seated catagenesis in the Posidonia Shale of the Lower Saxony Basin (Jochum et al., 1995). Their

108 interpretation was based on the incidence of calcite-filled fractures in layers that both are rich in organic

109 matter and are thermally mature. Posidonia shale layers meeting neither or only one of these criteria lack

110 such fractures. The wrapping of laminae produces a shear strain of roughly 0.45 , consistent with the wide

111 aspect ratio of the fractures. These findings cast suspicion on interpretations of ductile flowing textures as

112 soft-sediment deformation, in that demonstrably early fractures appear to form by brittle cracking, and

113 demonstrably late fractures develop high-shear-strain, flowing textures in their vicinities.

115 Petrography can provide crucial evidence about whether fracture sealing occurred during or after fracture

116 opening. As reviewed by Bons et al. (2012), the texture of mineral cements within fractures varies

117 sensitively with the fracture opening history. Cements deposited during fracture opening have only

118 limited pore space for growth, and will tend to display fibrous shapes (Hilgers et al., 2001; Hooker and

119 Cartwright, 2016), and crack-seal texture (Ramsay, 1980).

120

121 In contrast, mineral cements that postdate fracture opening tend to show blocky habits, indicating crystal

122 nucleation and growth within an open void having dimensions that are large in comparison to the crystal

123 size (Bons et al., 2012). For very small crystal sizes, postkinematic cements may coat fracture walls, as is

124 the case in laminated travertines and agates. Such cements may begin precipitating during fracture

125 opening but grow more slowly than fractures open, such that it is unclear how much time has elapsed

126 between fracture opening and cement precipitation.

127

128 2.3. Stable isotopes 
If the timing of mineral cements can be constrained to the opening of fractures, then chemical signatures

131 of those cements may reflect fluid conditions during fracturing. Carbon and oxygen isotopes are readily

132 measured from carbonate cements and can reveal useful, if indirect, evidence for fracture timing.

In most mudrocks, two large carbon pools for sourcing fracture-filling carbonates include inorganic

135 carbon from carbonate minerals in the host sediment, and the carbon from organic matter. The inorganic

136 pool is expected to have $\delta^{13} \mathrm{C}$ values near those of seawater through time-roughly 0\%o VPDB. The

137 organic pool is significantly depleted, by $30 \%$ or more, owing to preferential uptake of ${ }^{12} \mathrm{C}$ by biological

138 processes (Galimov, 1969). If fractures form amid externally derived fluids, then the carbon signature

139 would reflect those fluids, but the low permeability of mudrocks warrants using those two local carbon

140 pools as a starting point for interpreting vein carbon.

141

142 Oxygen is present in water as well as in dissolved carbonate species. Fractionation of oxygen during

143 carbonate mineral precipitation leaves the mineral enriched in ${ }^{18} \mathrm{O}$ with respect to the fluid, but this effect

144 is smaller at higher temperatures (Friedman and O’Neil, 1977). Therefore, carbonate minerals precipitated

145 at higher temperatures have lighter oxygen compositions, for a given fluid composition. Fractures that

146 seal within a closed system, with a low fluid volume and sealing minerals sourced from local

147 components, would be expected to have bulk isotopic compositions close to those of the host-rock

148 components.

150 Vein oxygen is commonly isotopically lighter than that of the host material (Figure 3). A notable

151 exception is cone-in-cone calcite hosted inside Proterozoic, organic-rich shale (Parnell et al., 2013). Apart

152 from this example, oxygen is depleted within veins, relative to the host rock, and the absence of any

153 general correlation likely reflects the control of the local temperature on oxygen fractionation. Vein

154 carbon is generally quite similar to that of the host carbonate (Figure 3), with a slightly greater tendency

155 toward depletion than enrichment within veins, presumably reflecting incorporation of organic carbon 
into vein cement. Hooker et al. (2017b) interpreted apparent enrichment of vein cement in the Marcellus

157 Formation to actually reflect depletion of both the host-rock and vein carbonate by mixing with organic 158 carbon, which affected the host-rock carbonate to a greater extent because of its smaller grain size.

\subsection{Thermometric constraints}

In many settings, temperature histories can be constrained, using some combination of stratigraphic

163 constraints, vitrinite reflectance, fission-track annealing, illite dating, and diagenetic fluid inclusions. If 164 the temperature during fracture opening can be determined, then that temperature can be linked with the 165 thermal history of the geologic setting.

167 Fracture opening temperatures can be constrained using fluid inclusion homogenization temperatures 168 (Foreman and Dunne, 1991; Evans et al., 2012; Gasparrini et al., 2013;) or clumped isotope ratios 169 (Quesnel et al., 2016) collected from synkinematic fracture cements. Fluids are trapped within inclusions 170 at ambient pressure-temperature conditions, such that upon cooling, a single-phase fluid inclusion 171 commonly nucleates a second phase, i.e., a vapor bubble (Goldstein and Reynolds, 1994). By heating 172 fluid inclusions to the point of phase homogenization, a minimum estimate of the trapping temperature is 173 obtained (Goldstein and Reynolds, 1994). In many cases, particularly in rocks rich in organic matter, the 174 ambient fluid is saturated with methane, and so the fluid forms a vapor bubble upon any cooling past the 175 trapping temperature. Therefore, the homogenization temperature equals the trapping temperature (e.g., 176 Evans and Battles, 1999). Thus, fluid inclusions represent a potentially powerful tool for constraining 177 fracture timing in organic-rich mudrocks. On the other hand, mudrock fractures commonly seal with 178 carbonate cements, which tend to deform plastically at low temperatures, compared to rigid silicate 179 cements. If the volume of fluid inclusions changes, the homogenization temperatures do not reliably 180 reflect trapping temperatures (Goldstein and Reynolds, 1994). 
Fluid inclusion compositions can be identified using various methods, often allowing the coupling of fluid composition and temperature data. In addition to diagnosing methane, depressed ice-melting temperatures

184 provide a proxy for salinity (e.g., Hooker et al., 2015). Raman spectroscopy can also identify chemical 185 species within fluid inclusions (e.g., Fall et al., 2015).

187 Another option for establishing the temperature of carbonate cement precipitation is clumped isotopes.

188 Unlike fractionation of carbon and oxygen isotopes, the tendency for heavy isotopes $\left({ }^{13} \mathrm{C},{ }^{18} \mathrm{O}\right)$ to "clump"

189 together in the same carbonate molecule varies only by temperature, and not by fluid composition

190 (Huntington and Lechler, 2015). That is, the clumping of heavy isotopes within a molecule is a purely

191 stochastic process at high temperature, but is systematically over-represented (relative to randomly

192 distributing isotopes among molecules) as temperature decreases. As such, the temperature of

193 precipitation of carbonate cements can be independently constrained using clumped isotope abundances.

195 Secondary alteration can change the clumping of isotopes in original crystals. For cements exposed to 196 elevated temperatures for extended periods of time, the laboratory clumped isotope signal may represent a 197 temperature higher than the precipitation temperature, up to the maximum exposure temperature (Ritter et 198 al., 2015).

\subsection{Radiometric age dating}

201

202 The potential for radiometric age-dating techniques to constrain the timing of opening mode fractures is

203 apparent but largely untapped. Uranium substitutes for calcium in carbonate lattices, and so has

204 considerable potential as a chronometer (Rasbury and Cole, 2009). Israelson et al. (1996) age-dated a

205 cone-in-cone sample using U-Pb ratios, and found the calcite precipitated some $30 \mathrm{~m} . \mathrm{y}$. after host-

206 sediment deposition. U-series disequilibrium (i.e., U-Th) measurements can constrain the timing of

207 relatively recent calcite veins, including hydrothermal veins (Sturchio and Binz, 1988; Kolodny et al., 

2014) and fault-related veins (Uysal et al., 2011), but to our knowledge has not been applied to mudrockhosted veins. Apart from these studies, most age-dates are from fault cements, whether using

210 disequilibrium series (Gutmanis et al., 1991) or equilibrium (i.e., U-Pb-Coogan et al., 2016; Roberts and

211 Walker, 2016; Nuriel et al., 2017), where carbonate slickenfibres are demonstrably synkinematic and may

212 be uranium-rich. Both uranium dating techniques hold promise for opening-mode fractures having 213 synkinematic carbonate fills.

215 Rhenium-osmium systematics are also of potential use in age-dating pyrite veins (Dichiarante et al., 2016) 216 and organic material (Selby et al., 2005). In the case of hydrocarbons, age dates from Re-Os can record 217 the timing of hydrocarbon generation (Selby and Creaser, 2005), and therefore potentially age-date 218 fractures that formed as a result of hydrocarbon generation.

\section{DISCUSSION}

224 It is generally accepted that the sealing of fibrous veins keeps up with fracture opening, such that little or 225 no fracture porosity is present during the growth process (Bons et al., 2012). Landry et al. (2016) noted 226 that despite the low porosity of mineral fills, they could nonetheless represent sites of enhanced 227 permeability, relative to the host mudrocks. In any case, the nature of the permeability - transient and 228 long-lasting — of mineralized fractures in mudrocks is still largely unresolved. Are vein fibres surrounded 229 by a fluid film that allows continual material transport to vein walls, and potentially enhances

230 permeability? Or do such veins open by the crack-seal mechanism, in which a large number of discrete 231 fracture events are near-perfectly localized upon the vein-rock interface, which is intermittently firmly 232 bonded? The presence of a median zone at the centre of veins, from which fibres emanate, suggests an 233 initial hydrofracture which is sealed and then expanded (Bons et al., 2012). As such, antitaxial veins 
234 resemble strain fringes (Koehn et al., 2000) around sealed hydrofractures, and the high angle between 235 fibres and this fracture suggests formation in a similar stress field. But are the mechanisms that initiate 236 and widen the veins the same?

\subsection{Fracture and bedding orientation}

A first step toward interpreting fracture mechanisms in mudrocks is the orientation of fractures. In Figure the illustrated default stress case (Figure $4 \mathrm{~A}$ ) represents $\mathrm{K}_{0}$ loading with $\sim 1.6 \mathrm{~km}$ overburden (40 MPa) and $\sigma_{\mathrm{H}}$ roughly $70 \%$ of the overburden, or $\sim 28 \mathrm{MPa}$. and Suppe, 1991; Becker and Gross, 1996; Engelder and Peacock, 2001; Rijken and Cooke, 2001).

249 Presumably this absence reflects the lower stiffness of the mudrocks, and thus the lower tensile stress 250 within them for the same lateral extension. In contrast, as pointed out by Gudmundsson and Brenner 251 (2001), vertical fractures might preferentially develop in mudrocks — and arrest at limestones or 252 sandstones - if the fractures are driven by fluid-pressure increases (Figure 4B, C, D) amid constant 253 remote compression. Such a stress state could result from a fixed lateral boundary, which would produce 254 greater compressive stress in stiffer rocks; i.e., limestones and sandstones, preventing opening-mode 255 fracture formation.

257 A large subset of fibrous, mudrock-hosted veins lie parallel to bedding, suggesting internal pressuring that 258 exceeded the overburden stress. In normal or strike-slip faulting stress regimes, fluid pressure increases 259 may impart a poroelastic effect that counteracts the overburden and the lateral stress in proportion 
(Engelder and Fischer, 1994), flipping the vertical stress to be the least compressive stress by the time the

261 tensile failure criterion is reached (Figure 4D). Apart from this possibility, it would be interpreted that

262 layer-parallel fractures form from fluid overpressure, like that illustrated in Figure 4C, but within a thrust-

263 faulting regime, in which the overburden is the least compressive stress. However, increases in lateral

264 tectonic compression could also drive open layer-parallel fractures (Figure 4E). In principle, lateral

265 compression would shift the representation of the lateral stress to the right on Mohr's circle, but in an

266 extreme scenario, the added compression could be borne entirely by the fluid pressure, such that the only

267 change in effective stress would be a corresponding decrease in the effective overburden.

269 There is a remarkable paucity of unambiguous syntaxial crack-seal texture — distinct from fibrous

270 texture - within layer-parallel fractures. Presumably either such fractures are not purely cyclically-driven

271 hydrofractures, being the general interpretation of crack-seal veins; or if they are, the multiple cracking

272 events that form them are so well localized at the vein wall as to be imperceptible, petrographically. If

273 layer-parallel fractures in mudrocks are not cyclically opened by fluid pressures, are they therefore driven

274 open by crystallization pressure? Do they form early, under low overburden stress? Is the layer-parallel

275 fissility of shale important? Based on the previous interpretation that cone-in-cone forms in semi-lithified

276 material (Franks, 1969), Israelson et al. (1996) concluded that the 30 m.y. gap between host deposition

277 and cone-in-cone precipitation means that the hosting Alum Shale therefore had a protracted compaction

278 history. However, the interpretation that cone-in-cone is necessarily an early structure is at odds with

279 more recent observations. First, Hooker and Cartwright (2016) noted that cone-in-cone does not displace

280 organic-rich matrix relative to rigid crystalline grains, implying a coherence to the sediment during cone-

281 in-cone growth. Second, the high shear strains around deep-seated Posidonia Shale veins, and the fine-

282 scale host-material inclusions amid them (Figure 2), imply that such textures can form after considerable

283 consolidation. Whether they do as a general rule can be further addressed using the timing constraints

284 described above. 
Whether cone-in-cone forms in unconsolidated sediment or not, it is evident that some fractures do, by

287 virtue of their ptygmatic folding (Figure 1). In general, it is highly likely that significant inelastic

288 deformation takes place during the growth of mudrock fractures, based on the early timing of fractures,

289 the short propagation distances after considerable widening (Figure 2), and the general interpretation that

290 fibrous veins open at rates slower than potential crystal growth rates. As such, progress in understanding

291 the strain mechanisms, patterns, and short- and long-term fluid-flow effects of fracturing could be enabled

292 by accounting for the plastic nature of the fracturing material, especially in numerical modelling, which

293 has previously focused on deformation of an elastic medium.

294

295 3.3. Fracturing, fluids, and diagenesis

296

297 Preferential fracturing of mudrocks may stem from the low permeability and high content of organic

298 matter or soluble components of mudrocks. Fluid overpressure from organic matter maturation, derived

299 from local organic components, drove fracture opening in layer-parallel fibrous calcite veins (Jochum et

300 al., 1995; Zhang et al., 2016; Meng et al., 2017a) and at least assisted the opening of vertical fractures,

301 whose orientation was likely controlled by regional tectonics (Hooker et al., 2017b). Volume loss from

302 early silica diagenesis drove the opening of vertical, mudrock-hosted calcite veins (Hooker et al., 2017a).

303 Meng (2017b) showed that the intensity of vertical and layer-parallel fibrous gypsum veins correlates

304 directly with the amount of sedimentary gypsum in the host strata. These case studies all relied on

305 detailed analyses of fracture arrangements and mineralogies to tease out arguments over mechanisms, but

306 the majority of fractured outcrops are plagued by the ambiguity of final fracture patterns, which can be

307 generated by a variety of loading paths. Better constraints on timing, particularly from radiometric age-

308 dates, would go far toward discriminating tectonic mechanisms from thermal, diagenetic, or catagenetic

309 ones. 
311 Processes that assist the fracturing of mudrocks can open the fluid system within those mudrocks,

312 introducing fluids from distant sources. Such processes include folding and faulting (Evans et al., 2012;

313 Evans and Fischer, 2012) and hydrocarbon expulsion (Gasparrini et al., 2013). A number of geochemical

314 studies have documented compelling evidence for advection during fracture opening, and perhaps enabled

315 by fracture opening (Elburg et al., 2002; Hilgers and Sindern, 2005; Barker et al., 2006). These examples

316 generally include fracture sets that are products of intense tectonic deformation, are encased in limestones

317 or sandstones interbedded with shales, are in rocks subjected to low-grade metamorphism, or some

318 combination of the three.

However, for mudrock-hosted, opening-mode fractures that are isolated from faults, the preponderance of

321 evidence supports closed-system fluid behaviour. This evidence includes (i) fill textures indicating that

322 cement kept up with fracture opening (i.e., fibrous fill), so that the fracture was never particularly porous

323 throughout growth (Hilgers et al., 2001); (ii) fill mineralogy and fracture intensity that both vary

324 sensitively with the local stratigraphy (Franks, 1969; Hooker et al., 2017a), suggesting that fracture

325 propagation and fluid flow produced little cross-stratal migration; (iii) isotope geochemistry of fracture

326 and host-rock minerals (Hooker et al., 2017b), whose correspondence generally supports a low-fluid,

327 rock-buffered environment of fracturing; (iv) blunt tips, such that the fracture aperture decays rapidly

328 beyond the end of the median zone, implying little propagation during widening (Meng, 2017a); and (v) a

329 timing that commonly predates significant tectonic deformation (Foreman and Dunne, 1991; Maher et al.,

330 2016; Ukar et al., 2017), during which fluids commonly advect (Evans and Fischer, 2012).

332 Based on these generalizations, and acknowledging exceptions, we suggest that fluid-flow should not be

333 assumed based on the presence of opening-mode fractures in mudrocks. Nor should mechanisms that

334 involve flowing fluids, such as hydrocarbon expulsion and seepage stress be assumed. Those mechanisms

335 almost certainly play important roles in the evolution of some fracture sets, as previous studies have

336 shown. But the opening of layer-parallel fractures against gravity is sufficiently explained by fluid or 
crystal pressurization within a thrust-faulting stress state, or by poroelastic inversion of the minimum

338 effective stress due to fluid-pressurization in a laterally confined rock volume. Parsimony therefore

339 favours these mechanisms, but of course better constraints for fracture timing will provide better tests of

340 fracture mechanisms, which appear to vary significantly among geological settings.

\section{CONCLUSIONS}

344 The timing of mudrock-hosted fractures can be constrained using straightforward, well documented 345 criteria, such as crosscutting relationships, petrographic evidence, and stable isotopic and fluid-inclusion 346 analyses; as well as relatively nascent approaches, such as clumped isotopic evidence and radiometric age

347 dating. The evidence to date has demonstrated that mudrocks may fracture at any time during their burial 348 and uplift history, including before the completion of mechanical compaction. However, the shape, 349 connectivity, orientation, type and degree of mineral infill, and concomitant fluid-flow behaviour may 350 vary systematically with fracture timing or mechanism. Although fracturing in mudrocks can coincide 351 with, or enable, fluid flow, it appears that it need not. Whatever extent to which mudrock fractures do 352 transmit fluids can begin to be assessed by constraining fracture timing. 
Barker, S.L.L., Cox, S.F., Eggins, S.M., and Gagan, M.K., 2006. Microchemical evidence for episodic growth of antitaxial veins during fracture-controlled fluid flow. Earth and Planetary Science Letters 250,

$364331-344$.

Becker, A. and Gross, M.R., 1996. Mechanism for joint saturation in mechanically layered rocks: an example from southern Israel. Tectonophysics 257, 223 - 237.

Bjørlykke, 2014. Relationships between depositional environments, burial history and rock properties. Some principal aspects of diagenetic process in sedimentary basins. Sedimentary Geology 301, $1-14$.

Bons, P.D., Elburg, M.A., and Gomez-Rivas, E., 2012. A review of the formation of tectonic veins and their microstructures. Journal of Structural Geology 43, $33-62$. continental crust: Insight from in situ U-Pb dating. Geology, doi:10.1130/G37212.1. cover in northern Switzerland recorded by calcite-celestite veins (Oftringen borehole, Olten). Swiss

383 Journal of Geoscience 104, 493 - 506,

Deming, D., Cranganu, C., and Lee, Y., 2002. Self-sealing in sedimentary basins. Journal of Geophysical Research 107 (B12), doi:10.1029/2001JB000504. 
Dichiarante, A.M., Holdsworth, R.E., Dempsey, E.D., Selby, D., McCaffrey, K.J.W., Michie, U. McL., Morgan, G., and Bonniface, J., 2016. New structural and Re-Os geochronological evidence constraining the age of faulting and associated mineralization in the Devonian Orcadian Basin, Scotland. Journal of the

391 Geological Society [London] 173, doi: 10.1144/jgs2015-118.

Elburg, M.A., Bons, P.D., Foden, J., and Passchier, C.W., 2002. The origin of fibrous veins: constraints from geochemistry. In de Meer, S., Drury, M.R., de Bresser, J.H.P, and Pennock, G.M., eds., Deformation Mechanisms, Rheology and Tectonics: Current Status and Future Perspectives. Geological Society [London] Special Publications 200, $103-118$.

Engelder, T. and Fischer, M.P., 1994. Influence of poroelastic behavior on the magnitude of minimum horizontal stress, $\mathrm{S}_{\mathrm{h}}$, in overpressured parts of sedimentary basins. Geology 22, $949-952$. Appalachian plateau: evidence showing mild penetrative strain does little to change the pristine appearance of early joints. Tectonophysics $336,31-41$.

404

Engelder, T. and Peacock, D.C.P., 2001. Joint development normal to regional compression during flexural-flow folding: the Lilstock buttress anticline, Somerset, England. Journal of Structural Geology $23,259-277$.

Engelder, T. and Whitaker, A., 2006. Early jointing in coal and black shale: Evidence for an Appalachian410 wide stress field as a prelude to the Alleghanian orogeny. Geology 34, $581-584$.

412 Evans, M.A., Bebout, G.E., and Brown, C.H., 2012. Changing fluid conditions during folding: An 413 example from the central Appalachians. Tectonophysics 576 - 577, $99-115$. 
415 Evans, M.A. and Battles, D.A., 1999. Fluid inclusion and stable isotope analysis of veins from the central

416 Appalachian Valley and Ridge province: implications for regional synorogenic hydrologic structure and 417 fluid migration. Geological Society of America Bulletin 111, $1841-1860$.

419 Evans, M.A. and Fischer, M.P., 2012. On the distribution of fluids in folds: A review of controlling 420 factors and processes. Journal of Structural Geology 44, 2 - 24.

421

422 Fall, A., Eichhubl, P., Bodnar, R.J., Laubach, S.E., and Davis, J.S., 2015. Natural hydraulic fracturing of 423 tight-gas sandstone reservoirs, Piceance Basin, Colorado. Geological Society of America Bulletin, doi: $424 \quad 10.1130 / \mathrm{B} 31021.1$.

Friedman, I. and O'Neil, J.R., 1977. Compilation of stable isotope fractionation factors of geochemical

434 interest. Geological Survey Professional Paper 440-KK, In Fleischer, M., ed., Data of Geochemistry

435 (Sixth ed.), Washington: United States Government Printing Office, 116 p. review and new observations. AAPG 98 (11), 2165 - 2216. 
441 production. Petroleum Geology Conference Series 7, $1131-1140$.

442

443 Galimov, E.M., 1969. Isotopic composition of carbon in gases of the crust. International Geology Review $44411,1092-1104$.

445

446 Gasparrini, M., Sassi, W., and Gale, J.F.W., 2013. Natural sealed fractures in mudrocks: A case study tied 447 to burial history from the Barnett Shale, Fort Worth Basin, Texas, USA. Marine and Petroleum Geology, 448 doi: 10.1016/j.marpetgeo.2013.12.006.

449

450 Goldstein, R.H. and Reynolds, T.J., 1994. Systematics of fluid inclusions in diagenetic minerals. SEPM 451 Short Course 31. Tulsa: SEPM (Society for Sedimentary Geology), 200 p.

452

453 Gudmundsson, A. and Brenner, S.L., 2001. How hydrofractures become arrested. Terra Nova 13, $456-$ 454462.

455

456 Gutmanis, J.C., Hailwood, E.A., Maddock, R.H., and Vita-Finzi, C., 1991. The use of dating techniques

457 to constrain the age of fault activity: a case history from north Somerset, United Kingdom. Quarterly

458 Journal of Engineering Geology 24, 363 - 374.

459

460 Heimhofer, U., Meister, P., Bernasconi, S.M., Ariztegui, D., Martill, D.M., Rios-Netto, A.R., and

461 Schwark, L., 2016. Isotope and elemental geochemistry of black shale-hosted fossiliferous concretions

462 from the Cretaceous Santana Formation fossil Lagerstätte (Brazil). Sedimentology, doi:

$463 \quad 10.1111 /$ sed.12337. 
Hilgers, C., Koehn D., Bons, P.D., and Urai, J.L., 2001. Development of crystal morphology during unitaxial growth in a progressively widening vein: II. Numerical simulations of the evolution of antitaxial

467 fibrous veins. Journal of Structural Geology 23, $873-885$.

468

Hilgers, C. and Sindern, S., 2005. Textural and isotopic evidence on the fluid source and transport mechanism of antitaxial fibrous microstructures from the Alps and the Appalachians. Geofluids 5, 239 471250.

472

473

Hiscott, R.N., 1979. Clastic sills and dikes associated with deep-water sandstones, Tourelle Formation, 474 Ordovician, Quebec. Journal of Sedimentary Petrology 49 (1), 1 - 10.

475

476

Hooker, J.N., Larson, T.E., Eakin, A., Laubach, S.E., Eichhubl, P., Fall, A., and Marrett, R., 2015.

477 Fracturing and fluid flow in a sub-decollement sandstone; or, a leak in the basement. Journal of the

478 Geological Society [London] 172, $428-442$.

479

480

Hooker, J.N. and Cartwright, J., 2016. Dolomite overgrowths suggest a primary origin of cone-in-cone.

481 Geological Magazine, doi: 10.1017/S0016756816000807.

482

483

Hooker, J.N., Huggett, J.M., Cartwright, J., and Ali Hussein, M., 2017a. Regional-scale development of

484 opening-mode calcite veins due to silica diagenesis. Geochemistry, Geophysics, Geosystems 18, doi:

$48510.1002 / 2017 \mathrm{GC006888}$.

486

487 Hooker, J.N., Cartwright, J., Stephenson, B., Silver, C.R.P., Dickson, A.J., and Hsieh, Y.-T., 2017b. Fluid 488 evolution in fracturing black shales, Appalachian Basin. AAPG Bulletin 101 (8), 1203 - 1238. 
Hudson, J.D., Coleman, M.L., Barreiro, B.A., and Hollingworth, N.T.J., 2001. Septarian concretions from

491 the Oxford Clay (Jurassic, England, UK): involvement of original marine and multiple external pore

492 fluids. Sedimentology 48, $507-531$.

493

494 Huntington, K.W., and Lechler, A.R., 2015. Carbonate clumped isotope thermometry in continental 495 tectonics. Tectonophysics $647-648,1-20$.

496

497 Ingram, G.M. and Urai, J.L., 1999. Top-seal leakage through faults and fractures: the role of mudrock 498 properties. In Aplin, A.C., Fleet, A.J., and Macquaker, J.H.S. (eds.), Muds and Mudstones: Physical and 499 Fluid-Flow Properties. Geological Society [London] Special Publications 158, 125 - 135.

500

501

Israelson, C., Halliday, A.N., and Buchardt, B., 1996. U-Pb dating of calcite concretions from Cambrian

502 black shales and the Phanerozoic time scale. Earth and Planetary Science Letters 141, 153 - 159.

503

504

Jochum, J., Friedrich, G., Leythaeuser, D., Littke, R., and Ropertz, B., 1995. Hydrocarbon-bearing fluid 505 inclusions in calcite-filled horizontal fractures from mature Posidonia Shale (Hils Syncline, NW Germany). Ore Geology Reviews 9, 363 - 370.

507

508

Karner, G.D. and Shillington, D.J., 2005. Basalt sills of the U reflector, Newfoundland Basin: A

509 serendipitous dating technique. Geology 33, $985-988$.

510

511 Koehn, D., Hilgers, C., Bons, P.D., and Passchier, C.W., 2000. Numerical simulation of fibre growth in 512 antitaxial strain fringes. Journal of Structural Geology 22, $1131-1324$.

514 Kolodny, Y., Burg, A., Geller, Y.I., Halicz, L., and Zakon, Y. 2014. Veins in the combusted metamorphic 515 rocks, Israel; Weathering or a retrograde event? Chemical Geology 385, 140 - 155. 
517 Landry, C.J., Eichhubl, P., Prodanović, M., and Wilkins, S., 2016. Nanoscale grain boundary channels in 518 fracture cement enhance flow in mudrocks. Journal of Geophysical Research: Solid Earth 121, doi:

$519 \quad 10.1002 / 2016 J B 012810$.

520

521 Lash, G., Loewy, S., and Engelder, T., 2004. Preferential jointing of Upper Devonian black shale,

522 Appalachian Plateau, USA: evidence supporting hydrocarbon generation as a joint-driving mechanism. In

523 Cosgrove, J.W. and Engelder, T., eds., The Initiation, Propagation, and Arrest of Joints and Other

524 Fractures. Geological Society [London] Special Publications 231, 129 - 151.

525

526

Li, R., Dong, S., Lehrmann, D., and Duan, L., 2013. Tectonically driven organic fluid migration in the

527

Dabashan Foreland Belt: Evidenced by geochemistry and geothermometry of vein-filling fibrous calcite

528 with organic inclusions. Journal of Asian Earth Sciences 75, 202 - 212.

529

530

Maher, H.D., Ogata, K., and Braathen, A., 2016. Cone-in-cone and beef mineralization associated with

Triassic growth basin faulting and shallow diagenesis, Edgeoya, Svalbard. Geological Magazine, doi: 10.1017/S0016756815000886.

534 Meng, Q., Hooker, J.N., and Cartwright, J., 2017a. Early overpressuring in organic-rich shales during 535 burial: evidence from fibrous calcite veins in the Lower Jurassic Shales-with-Beef Member in the Wessex 536 Basin, UK. Journal of the Geological Society [London], doi: 10.1144/jgs2016-146.

Meng, Q., Hooker, J.N., and Cartwright, J., 2017b. Lithological control on fracture cementation in the 539 Keuper Marl (Triassic), north Somerset, UK. Geological Magazine, doi: 10.1017/S001675681700070X. 
541 Narr, W. and Suppe, J., 1991. Joint spacing in sedimentary rocks. Journal of Structural Geology 13 (9),

$542 \quad 1038-1048$.

543

544 Nuriel, P., Weinberger, R., Kylander-Clark, A.R.C., Hacker, B.R., and Craddock, J.P., 2017. The onset of 545 the Dead Sea transform based on calcite age-strain analyses. Geology 45 (7), $587-590$.

546

547 Osborn, S.J., Macintosh, J.C., Hanor, J.S., and Biddulph, D., 2012. Iodine-129, ${ }^{87} \mathrm{Sr} /{ }^{86} \mathrm{Sr}$, and trace

548 elemental geochemistry of northern Appalachian brines: Evidence for basin-scale fluid migration and clay 549 mineral diagenesis. American Journal of Science 312, 263 - 287.

550

551 Parnell, J., Blamey, N.J.F., Costanzo, A., Feely, M., and Boyce, A.J., 2013. Preservation of

552 Mesoproterozoic age deep burial fluid signatures, NW Scotland. Marine and Petroleum Geology, doi:

$553 \quad 0.1016 /$ j.marpetgeo.2013.11.018.

554

555 Quesnel, B., Boulvais, P., Gautier, P., Cathelineau, M., John, C.M., Dierick, M., Agrinier, P., and 556 Drouillet, M., 2016. Paired stable isotopes $(\mathrm{O}, \mathrm{C})$ and clumped isotope thermometry of magnesite and 557 silica veins in the New Caledonia Peridotite Nappe. Geochimica et Cosmochimica Acta 183, $234-249$. 558

Ramsay, J.G., 1980. The crack-seal mechanism of rock deformation. Nature 284, 135 - 139.

560

Rasbury, E.T. and Cole, J.M., 2009. Directly dating geologic events: U-Pb dating of carbonates. Reviews

562 of Geophysics 47, RG3001, doi: 10.1029/2007RG000246.

564 Rijken, P. and Cooke, M.L., 2001. Role of shale thickness on vertical connectivity of fractures:

565 application of crack-bridging theory to the Austin Chalk, Texas. Tectonophysics 337, $117-133$. 
567 Ritter, A.-C., Kluge, T., Berndt, J., Richter, D.K., John, C.M., Bodin, S., and Immenhauser, A., 2015.

568 Application of redox sensitive proxies and carbonate clumped isotopes to Mesozoic and Palaeozoic

569 radiaxial fibrous calcite cements. Chemical Geology 417, 306 - 321.

570

571 Roberts, N.M.W. and Walker, R.J., 2016. U-Pb geochronology of calcite-mineralized faults: Absolute

572 timing of rift-related fault events on the northeast Atlantic margin. Geology 44 (7), $531-534$.

573

574 Selby, D., Creaser, R.A., Dewing, K., and Fowler, M., 2005. Evaluation of bitumen as a ${ }^{187} \operatorname{Re}-{ }^{187}$ Os

575 geochronometer for hydrocarbon maturation and migration: A test case from the Polaris MVT deposit,

576 Canada. Earth and Planetary Science Letters 325, $1-15$.

577

578 Selby, D. and Creaser, R.A., 2005. Direct radiometric dating of hydrocarbon deposits using rhenium-

579 osmium isotopes. Science 308, $1293-1295$.

580

581 Sturchio, N.C. and Binz, C.M., 1988. Uranium-series age determination of calcite veins, VC-1 drill core,

582 Valles Caldera, New Mexico. Journal of Geophysical Research 93 (B6), 6097 - 6102.

583

584 Torremans, K., Muchez, P., and Sintubin, M., 2014. Mechanisms of flexural flow folding of competent

585 single-layers as evidenced by folded fibrous dolomite veins. Journal of Structural Geology 69, $75-90$.

587 Ukar, E., Lopez, R., Laubach, S.E., Gale, J.F.W., Manceda, M., and Marrett, R., 2017. Microfractures in

588 bed-parallel veins (beef) as predictors of vertical macrofractures in shale: Vaca Muerta Formation, Agrio

589 fold-and-thrust belt, Argentina. Journal of South American Earth Sciences 79, 152 - 169. 
591 Uysal, I.T., Feng, Y.-x., Zhao, J.-x., Bolhar, R., Işik, V., Baublys, K.A., Yago, A., and Golding, S.D.,

592 2011. Seismic cycles recorded in late Quaternary calcite veins: Geochronological, geochemical and

593 microstructural evidence. Earth and Planetary Science Letters 303, 84 - 96.

594

595 Yu, H., Zhou, X., Wang, J., Guo, C., Wei, H., and Chen, D., 2015. The origin of bedding-parallel calcite

596 veins in the Lower Permian Chihsia Formation in western Hubei Province, South China. Science China

$597 \quad$ Press $60(20), 1778-1786$.

598

599 Zhang, J., Jiang, Z., Jiang, X., Wang, S., Liang, C., and Wu, M., 2016. Oil generation induces sparry

600 calcite formation in lacustrine mudrock, Eocene of east China. Marine and Petroleum Geology 71, $344-$ 601359.

602

603

604

605

FIGURE CAPTIONS

Figure 1. Ptygmatically folded calcite vein, Jordan Oil Shale. Modified from Hooker et al. (2017a). (A)

606 Core photo; horizontal field of view is $5 \mathrm{~cm}$. (B) Plane-polarized light; horizontal field of view is $4 \mathrm{~mm}$.

607 Note bent twin planes $(\mathrm{T})$ and microfracture of host material within inner arcs of the vein.

608

609 Figure 2. Low angle-to-bedding calcite veins, Posidonia Shale. (A) core photo; horizontal field of view is

$6108 \mathrm{~cm}$. (B) Backscattered scanning electron microscope image. Horizontal field of view is 500

611 micrometers. Yellow lines mark long axes of detrital grains. Calcite vein fill is pale grey near top of

612 image.

613

614 Figure 3. Stable isotopic compositions of carbonate vein fills and corresponding carbonate host-rock

615 components. (A) Oxygen; (B) carbon. Shaded boxes represent fractures within concretions. Dashed lines

616 represent cone-in-cone samples. References: a: de Haller et al., 2011; b: Gasparrini et al., 2013; c: 
617 Heimhofer et al., 2016; d: Hooker et al., 2017b; e: Hudson et al., 2001; f: Li et al., 2013; g: Meng et al.,

618 2017a; h: Parnell et al., 2013; i: Yu et al., 2015; j: Zhang et al., 2016.

619

620 Figure 4. Natural fractures in compliant mudrocks interbedded between stiff rocks. Left column illustrates

621 the mudrock fracture orientation; right column depicts the stress state and failure envelope in Mohr-circle

622 space. (A) Unfractured rock column with relaxed stress state (see text). This starting stress state is shown

623 dashed in (B-E). (B) Hypothetical effect of a volume shrinking diagenetic reaction, or of decreasing

624 lateral stress, as might result from tectonic extension. The overburden remains the same while the lateral

625 stress becomes more tensile. For lateral extension, we expect the stiff layers to fracture first. Large dashed

626 circle shows that shear failure would be expected unless the rocks were shallowly buried. Solid circles

627 illustrate the effective stress under elevated fluid pressure. (C) Effect of an increase in fluid pressure

628 within the shale, for example during catagenesis. Increased fluid pressure shifts the effective stress to

629 more tensile values. (D) Effect of increased fluid pressure as in (C), but also considering a poroelastic

630 effect, which counteracts the overburden and the lateral stress proportionally. (E) Effect of increased

631 lateral stress, as from tectonic compression that is borne purely by internal fluids. Solid circles indicate

632 that, if such a compression occurred amid already overpressured or shallowly buried rocks, the

633 compression could initiate horizontal opening-mode fractures. 


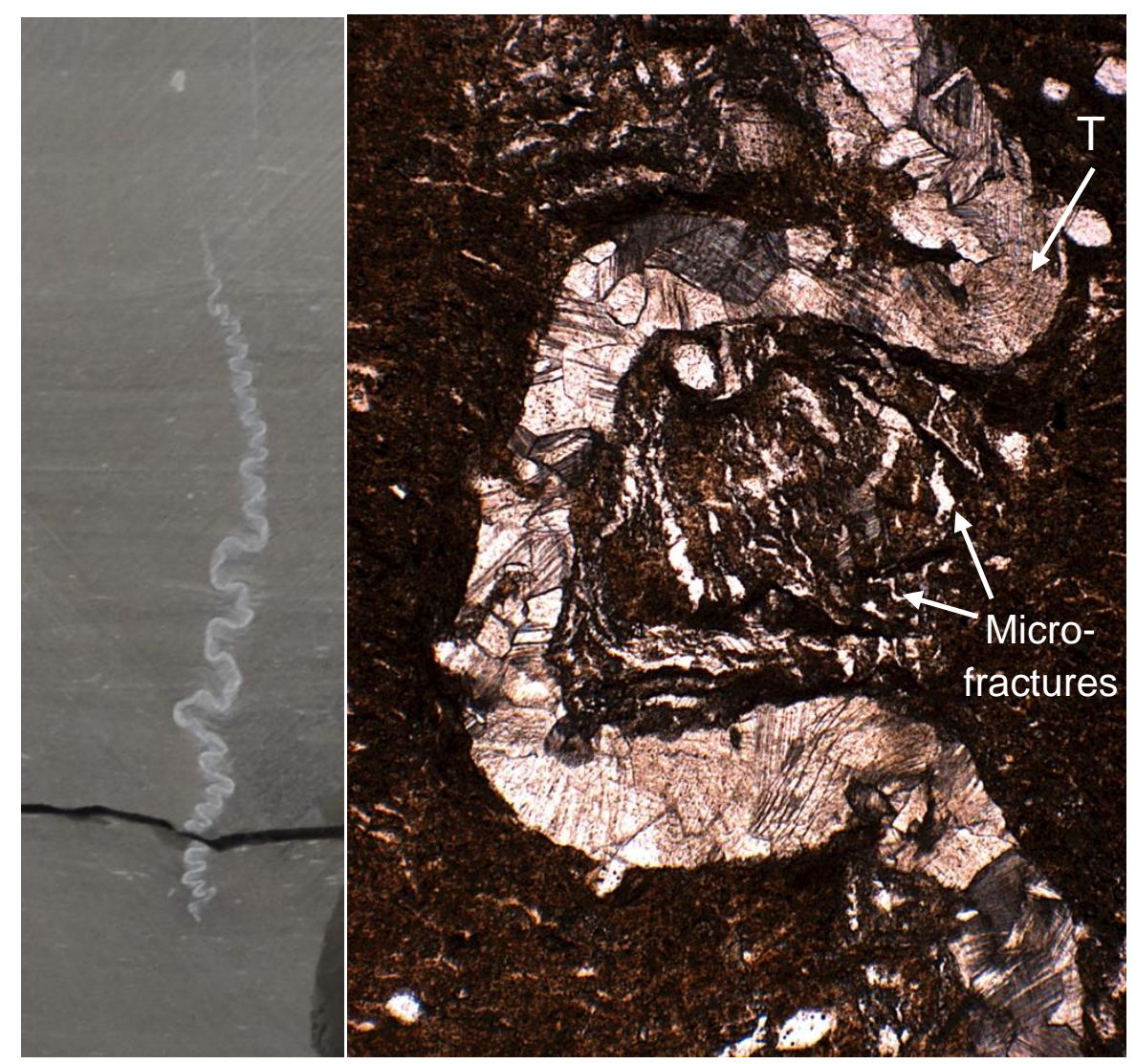

Figure 1. Ptygmatically folded calcite vein, Jordan Oil Shale. Modified from Hooker et al. (2017a). (A) Core photo; horizontal field of view is $5 \mathrm{~cm}$. (B) Plane-polarized light; horizontal field of view is $4 \mathrm{~mm}$. Note bent twin planes $(\mathrm{T})$ and microfracture of host material within inner arcs of the vein. 
(A) (B)

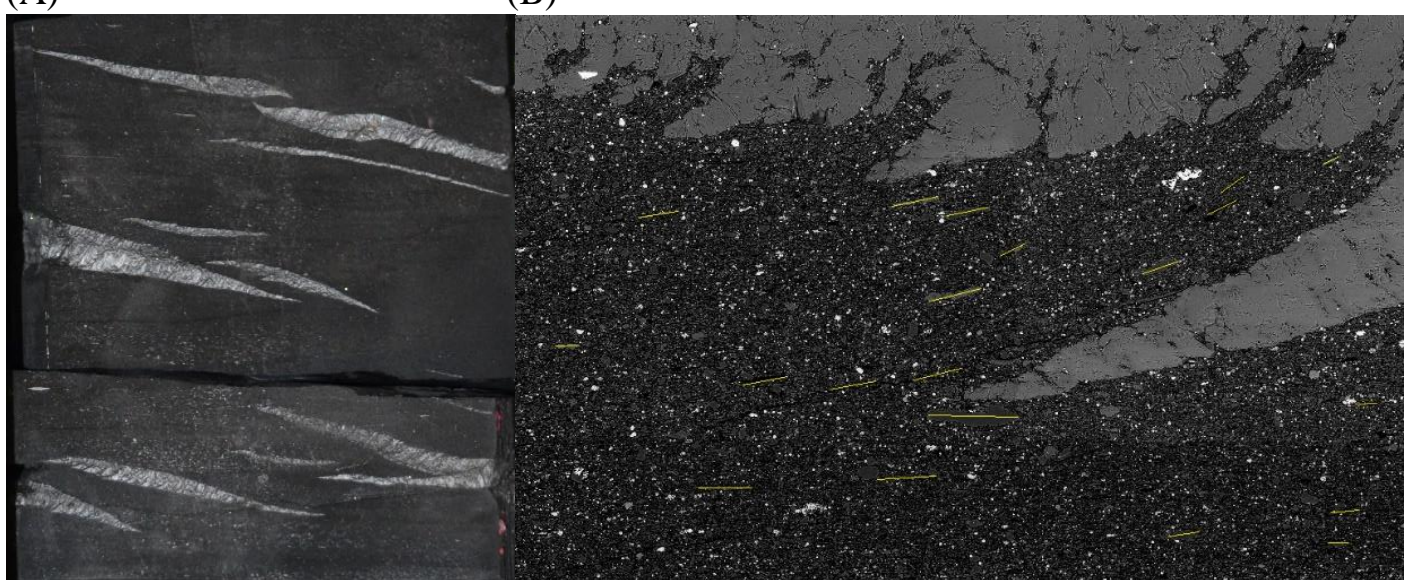

Figure 2. Low angle-to-bedding calcite veins, Posidonia Shale. (A) core photo; horizontal field of view is $8 \mathrm{~cm}$. (B) Backscattered scanning electron microscope image. Horizontal field of view is 500 $\mu \mathrm{m}$. Yellow lines mark long axes of detrital grains. Calcite vein fill is pale gray near top of image. (For interpretation of the references to colour in this figure legend, the reader is referred to the web version of this article.) 
A

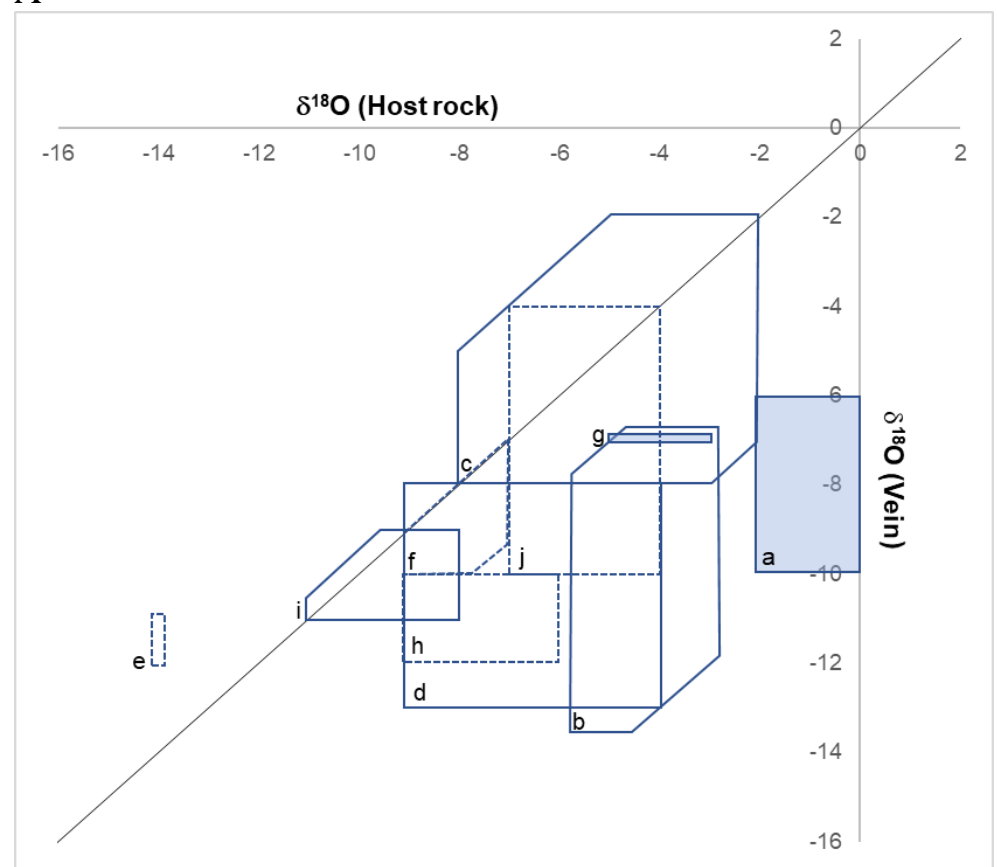

B

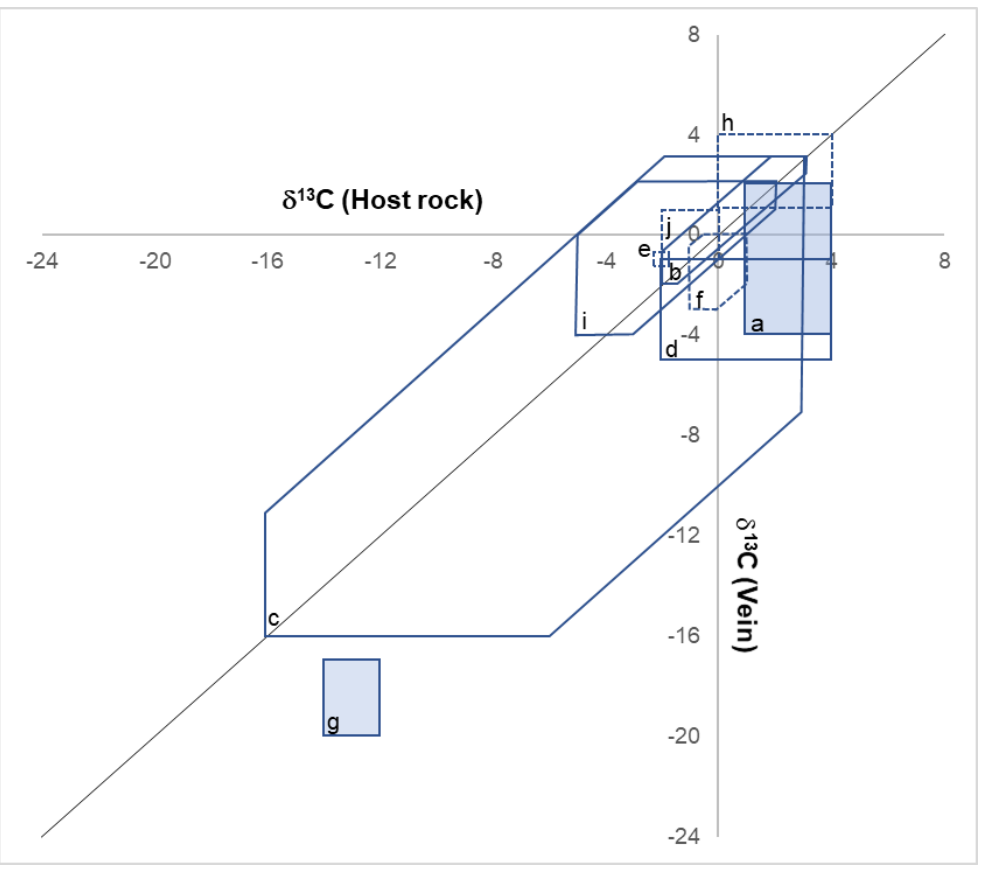

Figure 3. Stable isotopic compositions of carbonate vein fills and corresponding carbonate host-rock components. (A) Oxygen; (B) carbon. Shaded boxes represent fractures within concretions. Dashed lines represent cone-in-cone samples. References: a: Hudson et al., 2001; b: de Haller et al., 2011; c: Gasparrini et al., 2013; d: Li et al., 2013; e: Parnell et al., 2013; f: Yu et al., 2015; g: Heimhofer et al., 2016; h: Zhang et al., 2016; i: Hooker et al., 2017b; j: Meng et al., 2017a. 

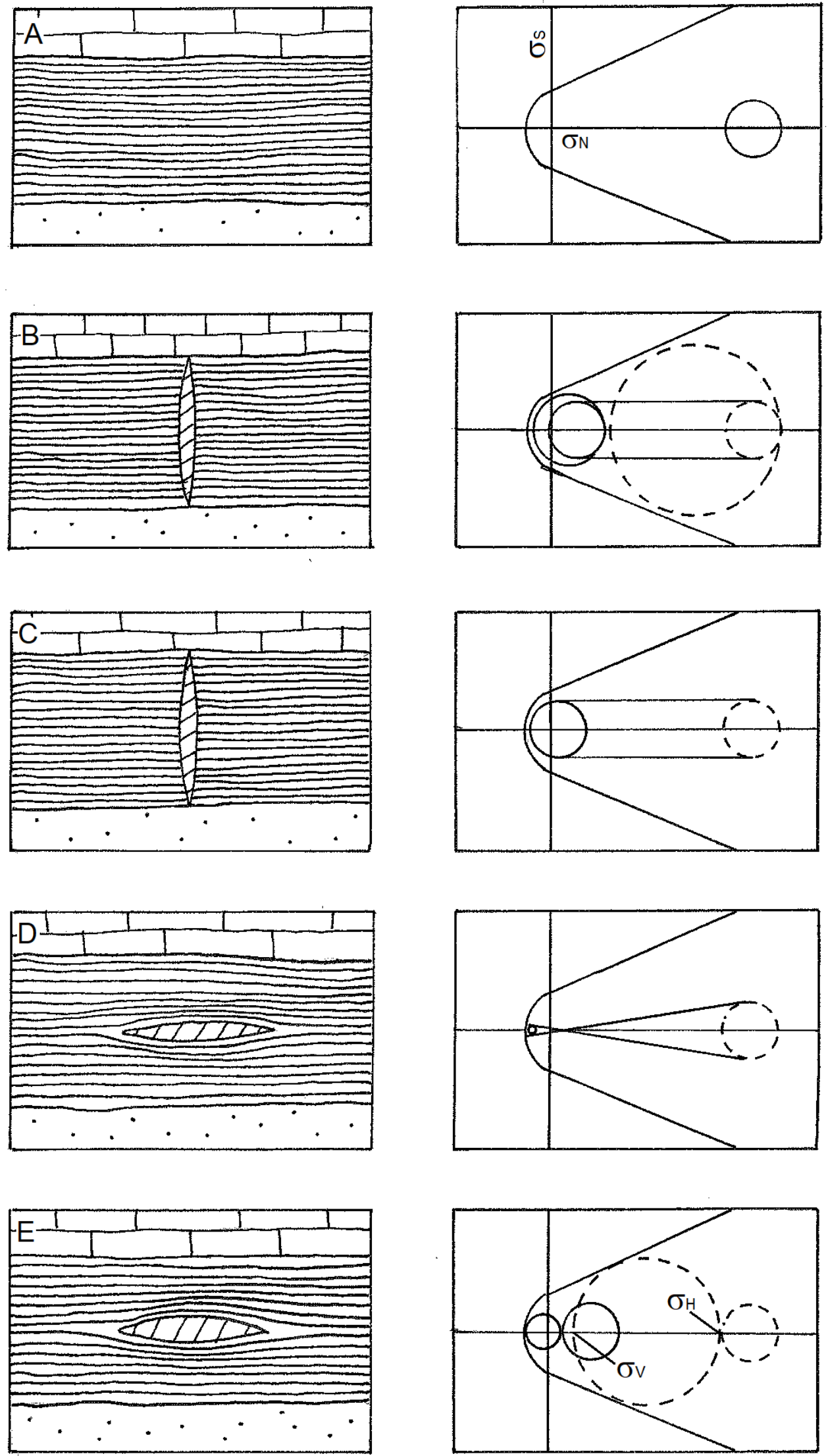
Figure 4. Natural fractures in compliant mudrocks interbedded between stiff rocks. Left column illustrates the mudrock fracture orientation; right column depicts the stress state and failure envelope in Mohr-circle space. (A) Unfractured rock column with relaxed stress state (see text). This starting stress state is shown dashed in (B-E). (B) Hypothetical effect of a volume shrinking diagenetic reaction, or of decreasing lateral stress, as might result from tectonic extension. The overburden remains the same while the lateral stress becomes more tensile. For lateral extension, we expect the stiff layers to fracture first. Large dashed circle shows that shear failure would be expected unless the rocks were shallowly buried. Solid circles illustrate the effective stress under elevated fluid pressure. (C) Effect of an increase in fluid pressure within the shale, for example during catagenesis. Increased fluid pressure shifts the effective stress to more tensile values. (D) Effect of increased fluid pressure as in (C), but also considering a poroelastic effect, which counteracts the overburden and the lateral stress proportionally. (E) Effect of increased lateral stress, as from tectonic compression that is borne purely by internal fluids. Solid circles indicate that, if such a compression occurred amid already overpressured or shallowly buried rocks, the compression could initiate horizontal opening-mode fractures. 